\title{
MENINGKATKAN MUTU PENDIDIKAN MELALUI MANAJEMEN PESERTA DIDIK
}

\author{
Bustanul Arifin \\ Dosen IAI TRIBAKTI Kediri \\ email: cak_bus@yahoo.com
}

\begin{abstract}
ABSTRAK
This paper discusses the improvement of the quality of education through students is one component in the education system that is important, in the world of education students are the raw material in the process of transforming science. Learning is a variety of components that are interconnected with one another. These components include objectives, material, methods and evaluation. The four components of learning must be considered by the teacher in choosing or determining the approach and learning model. Chasing activities in their implementation recognize many terms to describe the way of teaching that will be done by the teacher. At present there are so many kinds of learning strategies or methods that aim to improve the quality of learning to be better.
\end{abstract}

Keyword: Quality of Education, Management, Student Learning.

\section{PENDAHULUAN}

Peserta didik adalah anggota masyarakat yang berusaha mengembangkan potensi diri melalui proses pembelajaran, ${ }^{1}$ orang yang mengharapkan mendapat pelayanan pendidikan sesuai dengan bakat minat dan kemampuannya agar tumbuh dan berkembang dengan baik serta mempunyai kekuasaan dalam menerima pelajaran. Peserta didik mempunyai sebutan yang berbeda-beda dalam berbagai jenjang, pada taman kanak-kanak disebut anak didik, pada jenjang pendidikan dasar dan menengah disebut dengan siswa, dan pada jenjang pendidikan tinggi disebut mahasiswa. Selain itu sebutan lain bagi peserta didik yaitu murid, pembelajar, santri, trainee dan sebagainya. ${ }^{2}$

Peserta didik merupakan salah satu komponen dalam sistem pendidikan yang penting, dalam dunia pendidikan peserta didik merupakan bahan mentah di dalam proses transformasi ilmu pengetahuan. Peserta didik secara formal adalah

${ }^{1}$ Undang-undang Nomor 20 Tahun 2003 tentang Sistem Pendidikan Nasional Pasal 1 ayat 4

2 Tim Dosen Administrasi Pendidikan UPI, Manajemen Pendidikan, (Bandung: Alfabeta, 2011), 205

FALASIFA, Vol. 9 Nomor 2 September 2018 | 1 


\section{Bustanul Arifin}

orang yang sedang berada pada fase pertumbuhan dan perkembangan baik secara fisik maupun psikis, pertumbuhan dan perkembangan merupakan ciri dari seorang peserta didik yang perlu bimbingan dari seorang pendidik. ${ }^{3}$ Oleh sebab itu perlu manajemen yang baik agar peserta didik mempunyai kemampuan yang mumpuni ketika telah keluar dari sebuah lembaga pendidikan.

\section{PEMBAHASAN}

\section{Manajemen Peserta Didik}

Manajemen peserta didik bertujuan untuk mengatur dalam bidang kesiswaan agar kegiatan pembelajaran di sekolah itu berjalan lancar tertib dan teratur serta mencapai tujuan pendidikan sekolah. Untuk mewujudkan tujuan tersebut bidang manajemen peserta didik sedikitnya memiliki tiga tugas utama yang harus diperhatikan yaitu penerimaan murid baru, kegiatan kemajuan belajar serta bimbingan dan pembinaan disiplin. ${ }^{4}$ Manajemen peserta didik dapat diartikan sebagai usaha pengaturan terhadap peserta didik mulai dari peserta didik tersebut masuk sekolah sampai dengan mereka lulus. Yang diatur secara langsung adalah segi-segi yang berkenaan dengan peserta didik. Terhadap segi-segi lain selain peserta didik, dimaksudkan untuk memberikan layanan yang sebaik mungkin kepada peserta didik. ${ }^{5}$

Manajemen peserta didik adalah layanan yang memusatkan perhatian pada pengaturan, pengawasan, dan layanan siswa di kelas dan di luar kelas seperti pengenalan, pendaftaran, layanan individu seperti pengembangan keseluruhan kemampuan minat kebutuhan sampai dia matang di sekolah. Manajemen peserta didik bisa pula diartikan sebagai proses pengurusan segala hal yang berkaitan dengan siswa di suatu sekolah mulai dari perencanaan, penerimaan siswa, pembinaan yang dilakukan selama siswa berada disekolah, sampai dengan siswa menyelesaikan pendidikannya di sekolah.

Dengan kata lain manajemen peserta didik merupakan keseluruhan proses penyelenggaraan usaha kerjasama dalam bidang kesiswaan dalam rangka pencapaian tujuan pembelajaran di sekolah. Dengan demikian manajemen peserta didik itu bukanlah dalam bentuk kegiatan-kegiatan pencatatan peserta didik saja, melainkan meliputi aspek yang lebih luas, yang secara operasional dipergunakan untuk membantu kelancaran pertumbuhan dan perkembangan peserta didik

\footnotetext{
${ }^{3}$ Ramayulis, Ilmu Pendidikan Islam, (Jakarta: Kalam Mulia, 2008), 133

${ }^{4}$ Mulyasa, Manajemen Berbasis Sekolah cet 15, (Bandung: PT Remaja Rosdakarya, 2012), 46

${ }^{5}$ Imron, Manajemen Peserta Didik Berbasis Sekolah, (Jakarta: Bumi Aksara, 2015), 6
}

2 | FALASIFA, Vol. 9 Nomor 2 September 2018 
melalui proses pendidikan. ${ }^{6}$

2. Perencanaan Peserta Didik

Perencanaan peserta didik adalah suatu aktivitas memikirkan dimuka tentang hal-hal yang harus dilakukan berkenaan dengan peserta didik di sekolah, baik sejak peserta didik akan memasuki sekolah maupun mereka akan lulus dari sekolah. Yang direncanakan adalah hal-hal yang dikerjakan berkenaan dengan penerimaan peserta didik sampai dengan perumusan peserta didik. Langkahlangkah perencanaan peserta didik dimulai dengan perkiraan, rumusan tujuan, penyusunan program, penjadwalan, dan pembiayaan. ${ }^{7}$

Perencanaan terhadap peserta didik menyangkut penerimaan siswa baru, kelulusan, jumlah putus sekolah dan kepindahan. Khusus mengenai perencanaan peserta didik akan langsung berhubungan dengan kegiatan penerimaan dan proses pencatatan atau dokumentasi secara pribadi siswa, yang kemudian tidak dapat dilepaskan kaitannya dengan pencatatan atau dokumentasi data hasil belajar dan aspek-aspek lain yang diperlukan dalam kegiatan kurikuler dan kokurikuler. Langkah yang pertama yaitu perencanaan terhadap peserta didik yang meliputi kegiatan, analisis kebutuhan peserta didik, rekrutmen peserta didik, seleksi peserta didik, orientasi, penempatan peserta didik dan pencatatan serta pelaporan. ${ }^{8}$

Berkaitan dengan hal di atas diperlukan langkah perencenaan yang baik dimulai dari penerimaan peserta didik sampai dengan pengelolaan kelas, untuk memberikan layanan yang optimal kepada peserta didik.

a. Penerimaan Peserta Didik

Penerimaan peserta didik baru sebenarnya adalah salah satu kegiatan manajemen peserta didik yang sangat penting. Kebijakan operasional penerimaan peserta didik juga memuat sistem pendaftaran dan seleksi atau penyaringan yang akan diberlakukan untuk peserta didik. Selain itu kebijakan penerimaan peserta didik juga berisi mengenai waktu pendaftaran, kapan dimulai dan kapan diakhiri. Selanjutnya kebijakan penerimaan peserta didik harus juga memuat tentang personalia-personalia yang akan terlihat dalam pendaftaran seleksi dan penerimaan peserta didik. Kebijakan penerimaan peserta didik ini dapat dibuat berdasarkan petunjuk-petunjuk yang diberikan oleh Dinas Pendidikan Kota atau Kota. Petunjuk ini harus dipedomani karena memang dibuat dalam rangka mendapatkan calon peserta didik sebagaimana

\footnotetext{
${ }^{6}$ Hamiyah dan Mohammad Jauhar, Pengantar Manajemen Pendidikan di Sekolah, (Jakarta: Prestasi Pustaka, 2015), 35. Lihat pula E. Mulyasa, Menjadi Kepala Sekolah Profesional. (Bandung: PT. Remaja Rosda Karya, 2013), 44

${ }^{7}$ Imron, Manajemen Peserta..., 21

${ }^{8}$ Hamiyah dan Jauhar, Pengantar Manajemen ..., 45
}

FalASIFA, Vol. 9 Nomor 2 September 2018 | 3 
yang diinginkan atau didiamkan. ${ }^{9}$

Sistem seleksi dengan tes masuk adalah mereka yang mendaftar di suatu sekolah terlebih dahulu diwajibkan menyelesaikan serangkaian tugas yang berupa soal-soal tes. Jika yang bersangkutan dapat menyelesaikan suatu tugas berdasarkan kriteria tertentu yang telah ditentukan, maka ia akan diterima. Sebaliknya jika mereka tidak dapat menyelesaikan tugas berdasarkan kriteria atau aturan yang telah ditentukan tidak diterima sebagai peserta didik. ${ }^{10}$

Hasil penelitian yang dilakukan oleh Imron, dalam rekrutmen peserta didik baru, masalahnya adalah tidak dapat ditampungnya semua anak usia sekolah di daerah seputar sekolah. Faktor penyebabnya adalah terbatasnya piranti sekolah yang tersedia. Alternatif pemecahannya, menyalurkan anak usia sekolah yang tidak dapat ditampung tersebut ke Sekolah Dasar lainnya. Permasalahan lain dalam rekrutmen peserta didik adalah adanya anak yang usianya kurang dan 6 tahun tetapi orang tuanya tetap bersikukuh agar dapat diterima di SD. Faktor penyebahnya, orang tua tidak sabar dengan pendidikan anaknya. Alternatif pemecahannya, Kepala SD beserta guru memberikan pengertian kepada orang tua mengenai aturan rekrutmen peserta didik baru. ${ }^{11}$

Hal yang mempengaruhi strategi penerimaan siswa adalah keunggulan dan keragaman dari sekolah tersebut. Panitia penerimaan peserta didik baru, perlu menjukkan keunggulan dan keberagaman sekolah, agar masyarakat tertarik untuk menyekolahkan anaknya karena memang mutu dan kualitas sekolah setingkat lebih tinggi dibanding sekolah lain. ${ }^{12}$

b. Orientasi Peserta Didik

Orientasi peserta didik adalah kegiatan penerimaan siswa baru dengan mengenalkan situasi dan kondisi lembaga pendidikan, tempat peserta didik itu menempuh pendidikan. Tujuan diadakan kegiatan orientasi bagi peserta didik antara lain peserta didik dapat mengerti dan mentaati segala peraturan yang berlaku di sekolah, agar peserta didik dapat berpartisipasi secara aktif dalam kegiatan yang diselenggarakan sekolah, agar peserta didik siap menghadapi lingkungannya yang baru baik secara fisik, mental dan emosional sehingga ia

\footnotetext{
${ }^{9}$ Eka Prihatin, Manajemen Peserta Didik, (Bandung: Alfabeta, 2014), 51

${ }^{10}$ Imron, Manajemen Peserta..., 41

11 Ali Imron, Manajemen Peserta Didik di SD: Masalah, Penyebab, dan Alternatif
} Pemecahannya, Jurnal Ilmu Pendidikan, e-ISSN 2442-8655 Volume 5 Nomor 1 tahun 1998, 19

12 Destyana Ratih Pramachintya, dan Budi Sutrisno, Strategi Penerimaan Peserta Didik Baru di SD Muhammadiyah Program Khusus Boyolali, Jurnal VARIDIKA, p-ISSN 0852-0976 Volume 27 Nomor 1 tahun 2015, 57

4 | FalasIfa, Vol. 9 Nomor 2 September 2018 
merasa betah dalam mengikuti proses pembelajaran di sekolah serta dapat menyesuaikan dengan kehidupan sekolah. ${ }^{13}$

Lingkungan sekolah tempat belajar turut mempengaruhi tingkat keberhasilan belajar. Kualitas guru, metode mengajar, kesesuaian kurikulum dengan kemampuan anak, keadaan fasilitas perlengkapan sekolah, keadaan ruangan, jumlah murid tiap kelas, pelaksanaan tata tertib dapat mempengaruhi minat belajar dan hasil belajar peserta didik. Lingkungan sekolah terdiri dari sejumlah komponen penting sekolah, secara garis besar dibagi menjadi lingkungan fisik dengan non fisik. Lingkungan fisik terdiri dari sarana sekolah, prasarana sekolah baik itu perpustakaan, ruang kelas, gedung serta kelengkapan sekolah. Lingkungan sekolah yang non fisik meliputi interaksi antara guru dengan peserta didik, peserta didik dengan peserta didik yang lain. ${ }^{14}$

c. Pengelompokan Peserta Didik

Kepala sekolah dan staf guru perlu menyadari pentingnya identifikasi peserta didik dalam proses pembelajaran. Tindakan nyata yang harus dilakukan oleh lembaga untuk hal ini adalah bahwa dalam manajemen program tahunan sekolah, kegiatan identifikasi peserta didik dapat terakomodir dalam perencanaan dan pelaksanaannya, bukan hanya sampai disitu namun oleh karena proses ini sustainable dan terus menerus, aka evaluasi dalam konteks improvement dan upgrading perlu dilakukan. Tujuan dari identifikasi ini sesungguhnya adalah untuk mengenali potensi peserta didik. Berdasarkan potensi inilah kemudian peserta didik dikelompokkan sesuai dengan keberbakatan masing-masing peserta didik. ${ }^{15}$

Fungsi integrasi dalam pengelompokan peserta didik dilakukan berdasarkan umur jenis kelamin dan sebagainya. Fungsi perbedaan dalam pengelompokan peserta didik dilakukan berdasarkan perbedaan individu misalnya bakat kemampuan minat dan sebagainya. Selain kedua pertimbangan tersebut beberapa pertimbangan antara lain yang perlu diperhatikan adalah pengelompokan berdasarkan pertemanan, berdasarkan prestasi, berdasarkan kemampuan dan bakat, berdasarkan perhatian dan minat, yang terakhir berdasarkan kecerdasan. ${ }^{16}$

Lawes menyatakan bahwa pengelompokan peserta didik bisa dilakukan

${ }^{13}$ Tim Dosen Administrasi Pendidikan UPI, Manajemen Pendidikan, (Bandung: Alfabeta, 2011), Manajemen Pendidikan, 210

${ }^{14}$ Karwati, Euis, dan Priansa, Donni Juni, Manajemen Kelas, (Bandung: Alfabeta, 2015), 266

${ }^{15}$ P. Ratu Ile Tokan, Sumber Kecerdasan Manusia, Jakarta: Grasindo, 2016, 46

${ }^{16}$ Karwati dan Priansa, Manajemen Kelas, 151

FALASIFA, Vol. 9 Nomor 2 September 2018 | 5 
dengan perbandingan kondisi fisik, karakter intelektual, kualitas sosial. ....where children of the same age are compared for a mber of factors such as physical features (height, weight, eyesight, etc.); intellectual characteristics (intelligence, ability to learm, skill at languages, etc.); social qualities (friendliness, ability to lead, helpful behaviour, etc.).... ${ }^{17}$

Perbedaan tingkat kemampuan di kalangan peserta didik dalam pembelajaran seringkali ditemukan antara lain kemampuan ekonomi, kemampuan sosial, kemampuan kultural, dan terutama kemampuan intelektual. Merut tingkat kemampuan intelektual misalnya, paling tidak terdapat tiga tingkatan yaitu siswa pandai, siswa sedang dan siswa yang lemah, sehingga selalu tertinggal dari kawan-kawannya. Menghadapi realitas tingkat kemampuan yang berbeda-beda ini, seorang manajer kiranya dapat melakukan kegiatan tes penempatan dengan mengelompokkan mereka dalam kategori tertentu. Kelas A menampung peserta didik yang pandai, kelas B peserta didik yang kemampuannya menengah, kelas $\mathrm{C}$ menampung peserta didik yang lemah. Kebijakan ini membawa konsekuensi pengalokasian peserta didik secara homogen. Manajer dan pendidik seringkali dihadapkan pilihan yang sulit antara pengaturan kelas secara umum gen atau heterogen. Kedua-duanya memiliki kelebihan dan kelemahan masing-masing. ${ }^{18}$

d. Pengelolaan Kelas

Pengelolaan peserta didik merupakan layanan yang memusatkan perhatian pada pengaturan pengawasan dan layanan siswa di kelas maupun luar kelas. Tahapan pengelolaan peserta didik antara lain analisis kebutuhan peserta didik, rekrutmen peserta didik, seleksi peserta didik, orientasi peserta didik, penempatan peserta didik, pembinaan dan pengembangan peserta didik, pencatatan dan pelaporan kelulusan dan alumni. ${ }^{19}$

Pengelolaan peserta didik yang dimaksud peneliti disini adalah pengelolaan di dalam kelas, sehingga sering disebut sebagai manajemen kelas. Proses pengajaran di dalam kelas menjadi bagian dari pengelolaan kelas. Pembelajaran didalam kelas dapat dianggap memiliki empat komponen: Persiapan, Presentasi, Praktik, Kinerja. Meier menyampaikan :

${ }^{17}$ J. S. Lawes, and CT Eddy, Understanding Children, An Introduction To Psychology For African Teachers, London: Taylor \& Francis, 1966, 6 160

${ }^{18}$ Mujamil Qomar, Strategi Pendidikan Islam, (Jakarta: Penerbit Erlangga, 2013),

${ }^{19}$ Imam Machali, dan Ara Hidayat, The Handbook Education Management, Jakarta: Prenadamedia Group, 2016, 190

6 | FaLASIFA, Vol. 9 Nomor 2 September 2018 
All human learning can be thought of as having four components, Preparation (the arousal of interest), Presentation (the initial encounter of new knowledge or skill), Practice (the integration of the new knowledge or skill), Performance (the application of the new knowledge and skill to real-world situations). Unless all four components are present in one form or another, no real learning occurs. ${ }^{20}$

Manajemen kelas yang efektif perlu pendekatan komprehensif yang mencakup, penataan lingkungan sekolah dan kelas, aktif mengawasi keterlibatan siswa, melaksanakan peraturan kelas dan rutinitas, menerapkan prosedur yang mendorong perilaku yang tepat, menggunakan strategi pengurangan perilaku, mengumpulkan dan menggunakan data untuk memantau perilaku siswa, dan memodifikasi prosedur pengelolaan kelas sesuai kebutuhan. ${ }^{21}$

e. Evaluasi Hasil Belajar Peserta Didik

Evaluasi hasil belajar terhadap peserta didik perlu dilakukan agar diketahui perkembangan mereka dari waktu ke waktu. Evaluasi hasil peserta didik dimaksudkan untuk mengetahui sejauh mana peserta didik telah dapat menampilkan performa sesuai yang diinginkan. Tanggung jawab untuk mengevaluasi belajar ada ditangan pendidik. Agar evaluasi dapat mencapai sasarannya, para pendidik perlu berpedoman pada prinsip teknik-tekniknya. Secara garis besar teknik evaluasi dapat dibedakan menjadi dua itu tes dan non tes. $^{22}$

Seorang guru dalam melakukan evaluasi, tergantung pada penguasaan siswa dalam kompetensi tertentu setelah mengikuti proses pembelajaran. Evaluasi tersebut juga dapat bertujuan untuk mengetahui kesulitan belajar peserta didik. Tujuan evaluasi tersebut harus jelas sehingga memberikan arah dan lingkup pengembangan evaluasi selanjutnya ${ }^{23}$ Penilaian peserta didik pada jenjang pendidikan dasar dan menengah didasarkan pada prinsip objektif, terpadu, ekonomis, transparan. Standar penilaian pendidikan ditetapkan melalui Permendiknas nomor 20 tahun 2007, tentang standar penilaian pendidikan yang didalamnya mencakup mekanisme prosedur dan instrumen

${ }^{20}$ Dave Meier, The Accelerated Learning Handbook, New York: The McGraw-Hill Companies, Inc, 2000, 53

${ }^{21}$ Regina M. Oliver and Daniel J. Reschly, Effectife Classroom Management: Teacher Preparation and Professional Development, Washington: National Comprehensive Centre for Teacher Quality, 2007, 6

${ }^{22}$ Imron, Manajemen Peserta..., 116

${ }^{23}$ Sitiatava Rizema Putra, Desain Evaluasi Belajar Berbasis Kinerja, Yogayakarta: Diva Press, 2013, 101 


\section{Bustanul Arifin}

$$
\text { penilaian hasil belajar peserta didik. }{ }^{24}
$$

3. Peningkatan Mutu Pendidikan

Mutu merupakan proses terstruktur untuk memperbaiki keluaran yang dihasilkan. Mutu bukanlah benda magis atau sesuatu yang rumit. Mutu didasarkan pada akal sehat. Mutu menciptakan lingkungan bagi pendidik, orang tua, pejabat pemerintah, wakil-wakil masyarakat dan pemuka bisnis untuk bekerja sama guna memberikan para murid sumber daya yang dibutuhkan untuk memehi tantangan masyarakat, bisnis dan akademik mereka baik sekarang dan dimasa depan. Bila mutu pendidikan hendak diperbaiki, maka perlu ada pemimpin dari para profesional pendidikan. ${ }^{25}$

Bagi setiap institusi mutu adalah agenda utama dan tugas yang paling penting. Meskipun demikian, ada sebagian orang yang menganggap mutu sebagai sebuah konsep yang peh dengan teka-teki. Mutu dianggap sebagai suatu hal yang membingungkan dan sulit untuk diukur. Mutu dalam pandangan seseorang terkadang pertentangan dengan mutu dalam pandangan orang lain. Sehingga tidak aneh ketika ada dua pakar yang tidak memiliki kesimpulan yang sama tentang cara menciptakan institusi yang baik. ${ }^{26}$

Juran mendefinisaikan mutu sebagai berikut :

"Quality" means those features of products which meet customer needs and thereby provide customer satisfaction. In this sense, the meaning of quality is oriented to income. The purpose of such higher quality is to provide greater customer satisfaction and, one hopes, to increase income. However, providing more and/or better quality features usually requires an investment and hence usually involves increases in costs. Higher quality in this sense usually "costs more."27

Menurut pendapat Juran diatas, mutu diartikan sebagai karakteristik khusus yang dimiliki oleh suatu produk, yang memehi kebutuhan pelanggan dan dengan demikian memberikan kepuasan pelanggan. Mutu merut pengertian ini berorientasi pada pendapatan. Tujuan dari mutu yang lebih tinggi adalah untuk memberikan kepuasan pelanggan dan memehi harapan seseorang, untuk meningkatkan penghasilan. Akan tetapi penyediaan jenis mutu yang bermacammacam dan lebih baik, memerlukan investasi dan karenanya biasanya melibatkan

\footnotetext{
${ }^{24}$ Permendiknas Nomor 20 tahun 2007, tentang Standar Penilaian Pendidikan

25 Veithzal Rivai Zainal dkk, Islamic Quality Education Management, Jakarta: Gramedia, 2016, 122

${ }^{26}$ Edward Sallis, Total Quality Management in Education, Yogyakarta: Ircisod, 2015,23

${ }^{27}$ Joseph M. Juran and A. Blanton Godfrey, Juran's Quality Handbook Fifth Edition, New York: The McGraw-Hill Companies, Inc, 1998, 2.1
}

8 | FALASIFA, Vol. 9 Nomor 2 September 2018 
peningkatan pembiayaan. Kualitas yang lebih tinggi dalam pengertian ini biasanya memerlukan pembiayaan yang lebih mahal.

Gerakan mutu terpadu dalam pendidikan masih tergolong baru. Ada sedikit literatur yang memuat referensi tentang hal ini sebelum tahun 1980-an. Beberapa upaya reorganisasi terhadap praktek kerja dengan konsep Total Quality Management (TQM) telah dilaksanakan oleh beberapa universitas di Amerika. Baru pada awal tahun 1990-an, metode TQM menjadi semacam kebutuhan dan dilaksanakan dibeberapa perguruan tinggi lain. Adanya banyak gagasan yang dihubungkan dengan mutu juga dikembangkan dengan baik oleh institusi institusi pendidikan tinggi. Gagasan terus-menerus diteliti dan diimplementasikan sekolahsekolah. ${ }^{28}$

Manajemen mutu merupakan sarana yang memungkinkan para profesional pendidikan untuk dapat beradaptasi dengan kekuatan perubahan yang memukul sistem pendidikan. Pengetahuan yang diperlukan untuk memperbaiki sistem pendidikan sebenarnya sudah ada dalam komunitas pendidikan kita sendiri. Kesulitan utama yang dihadapi para profesional pendidikan saat ini adalah ketidakmampuan dalam menghadapi sistem yang gagal, sehingga menjadi tabir bagi para profesional pendidikan itu untuk mengembangkan atau menerapkan proses baru pendidikan yang akan memperbaiki mutu pendidikan. ${ }^{29}$

Sekolah yang efektif dan berorientasi pada mutu pendidikan memerlukan komitmen yang peh kesungguhan dalam peningkatan mutu, berjangka panjang dan membutuhkan penggunaan peralatan dan teknik-teknik tertentu. Komitmen tersebut harus didukung oleh dedikasi yang tinggi terhadap mutu melalui penyempurnaan proses yang berkelanjutan oleh semua pihak. Aspek dan indikator pengelolaan lembaga pendidikan dapat dijalankan dan diarahkan ke sebuah mutu yang tinggi, sehingga keberhasilan dari pencapaian mutu tersebut harus merupakan integrasi dari semua keinginan dan partisipasi stakeholder dalam pencapaian hasil akhirnya. ${ }^{30}$

Beberapa langkah yang ditempuh untuk meningkatkan mutu pendidikan diantaranya adalah :

a. Peningkatan Mutu Input

Input pendidikan merupakan sesuatu yang harus tersedia untuk berlangsungnya proses pendidikan. Sesuatu yang harus tersedia itu berupa sumber daya manusia dan sumber daya bukan manusia (buman resources and

\footnotetext{
${ }^{28}$ Sallis, Total Quality ..., 36

${ }^{29}$ Ibid

${ }^{30}$ Amri, Peningkatan Mutu ..., 18
}

FaLASIFA, Vol. 9 Nomor 2 September 2018 | 9 


\section{Bustanul Arifin}

non human resources), perangkat lunak, dan harapan-harapan sebagai pemandu bagi berlangsungnya proses pendidikan. Input sumber daya manusia meliputi kepala sekolah, guru, konselor, siswa, dan karyawan. Sedangkan input sumber daya bukan manusia meliputi antara lain peralatan, perlengkapan, dana, bahan, dan lain-lain. ${ }^{31}$

1) Sumberdaya Manusia

Pengembangan kualitas sumber daya manusia (SDM) bukan persoalan yang gampang dan sederhana, karena membutuhkan pemahaman yang mendalam dan luas pada tingkat pembentukan konsep dasar tentang manusia serta perhitungan yang matang dalam penyiapan institusi dan pembiayaan. ${ }^{32}$ Upaya pengembangan dan peningkatan kualitas sumber daya manusia dapat dilakukan melalui berbagai jalur, diantaranya melalui pendidikan. Pendidikan ini merupakan jalur peningkatan kualitas sumber daya manusia yang lebih menekankan pada pembentukan kualitas dasar, misalnya keimanan dan ketakwaan, kepribadian, kecerdasan, kedisiplinan, kreativitas dan sebagainya. ${ }^{33}$

SDM dalam dunia pendidikan terbagi atas pendidik dan tenaga kependidikan, yang terpenting adalah pendidik. Tugas pendidik dalam usaha membimbing dan mendidik peserta didik agar memiliki kepribadian muslim membawa konsekuensi-konsekuensi khusus bagi pendidik, antara lain pendidik harus memberikan teladan bagi peserta didik antara lain, memiliki wawasan keilmuan yang mendalam, bersedia menambah pendidikan guna memehi persyaratan standar minimal kelayakan sebagai pendidik, dan bersedia mengikuti berbagai kegiatan ilmiah. ${ }^{34}$

Ahmad Sasi mengemukakan jika abad silam disebut kualitas produk, maka masa yang akan datang merupakan abad kualitas SDM. SDM yang berkualitas dan pengembangan kualitas SDM bukan lagi merupakan isu atau tema-tema retorik, melainkan merupakan taruhan atau andalan serta ujian setiap individu, kelompok, golongan masyarakat dan bahkan setiap bangsa. ${ }^{35}$

${ }^{31}$ Depdiknas, Manajemen Peningkatan Mutu Berbasis Sekolah, Buku 1, Konsep dan Pelaksanaan (Jakarta: Dirjen Dikdasmen, 2001), 18-20

${ }^{32}$ A. Malik Fajar, Reorientasi Pendidikan Islam, (Jakarta: Fajar Dunia, 1999, Cet. I), 156

${ }^{33}$ Abdul Latif, Pengembangan Sumber Daya Manusia yang Berkualitas Menghadapi Era Pasar Bebas, (Jakarta: DPP HIPPI, 1996), 11

${ }^{34}$ Qomar, Strategi Pendidikan..., 146

${ }^{35}$ Ahmad Sasi, Pendidikan Alternatif, (Bandung: Grafindo Media Pratama, 1998), 7

10 | FALASIFA, Vol. 9 Nomor 2 September 2018 
2) Sarana dan Prasarana

Undang-Undang Republik Indonesia No 20 tahun 2003 pasal 45 memuat tentang pentingnya sarana dan prasarana pendidikan. Pasal 45 menyebutkan bahwa setiap satuan pendidikan formal dan non formal menyediakan sarana dan prasarana yang memehi keperluan pendidikan sesuai dengan pertumbuhan dan perkembangan potensi fisik, kecerdasan intelektual, sosial, emosional, dan kewajiban peserta didik. ${ }^{36}$

Sarana dan prasarana pendidikan ini juga diatur oleh Peraturan Pemerintah $^{37}$ yang menyatakan bahwa setiap satuan pendidikan wajib memiliki sarana yang meliputi : perabot, peralatan pendidikan, buku dan sumber belajar lainnya, bahan habis pakai serta perlengkapan yang diperlukan untuk menjang proses pembelajaran yang teratur dan berkelanjutan. Setiap satuan pendidikan hendaknya meliputi: lahan, ruang kelas, ruang pimpinan, ruang guru, ruang perpustakaan, ruang laboratorium, kantin, tempat berolah raga dan tempat beribadah, tempat bermain, tempat rekreasi, dan ruang tempat lain yang diperlukan untuk menjang proses pemmbelajaran yang teratur dan berkelanjutan.

Manajemen sarana dan prasarana pendidikan bertugas mengatur serta menjaga sarana dan prasarana pendidikan agar dapat memberikan kontribusi pada proses pendidikan secara optimal dan berarti. Kegiatan pengelolaan ini meliputi kegiatan perencanaan, pengadaan, pengawasan, penyimpanan, inventarisasi, penghapusan serta penataan. ${ }^{38}$ Hasil penelitian yang dilakukan oleh Maulida $\mathrm{dkk}^{39}$, menjukkan bahwa proses perencanaan kebutuhan sarana dan prasarana pendidikan yang mencakup:

a) Pengadaan, merupakan proses perancangan upaya pembelian, penyewaan, peminjaman, pekaran, daur ulang, rekondisi/rehabilitasi, distribusi atau pembuatan peralatan dan perlengkapan yang sesuai dengan kebutuhan sekolah;

b) Pemerataan, dilakukan secara terbuka dan transparan terhadap pengguna melibatkan beberapa karyawan untuk mengatasi persoalan dan kesesuaian penerima sarana dengan agenda pemerataan;

${ }^{36}$ Undang-undang No 20 tahun 2003 tentang Sistem Pendidikan Nasional pasal 45

${ }^{37}$ Peraturan Pemerintah Nomor 32 tahun 2013 tentang perubahan atas Peraturan Pemerintah No 19 tahun 2005 tentang Standar Nasional Pendidikan Bab VII pasal 42 ayat 1 dan 2

${ }^{38}$ Mujamil Qomar, Manajemen Pendidikan Islam, (Jakarta: Erlangga, 2007), 171

${ }^{39}$ Maulida dkk, Manajemen Sarana dan Prasarana Pendidikan pada SMA Negeri 5 Banda Aceh, Jurnal Mudarrisuna, e-ISSN 2460-0733 Volume 6 Nomor 1, 140-141

FalAsIfa, Vol. 9 Nomor 2 September 2018 | 11 
c) Pemanfaatan sarana dan prasarana sudah mengarah pada proses pencapaian tujuan, meskipun dalam pelaksanaannya, pemanfaatan sarana dan prasarana pendidikan sering mengalami tumpang-tindih antara petunjuk dan teknis penggunaan. Penggunaan alat untuk semua kelas dapat dilakukan dengan membawa ke kelas yang membutuhkan secara bergantian atau siswa yang akan menggunakan mendatangi ruangan tertentu. Seperti mendatangkan alat ke kelas atau mendatangkan siswa ke ruang alat ada kebaikan dan keburukannya. Alat didatangkan ke kelas terjadi kelas tetap dan siswa mendatangi ruangan-ruangan terjadi kelas berjalan (kelas adalah sekelompok anak yang dalam waktu yang sama, dibawah bimbingan seorang guru).

b. Peningkatan Mutu Proses

Suatu proses pendidikan dikatakan bermutu tinggi apabila terjadi proses pengoordinasian, penyerasian, dan pemaduan berbagai input sekolah, baik yang tergabung dalam buman resources maupun non human resources, yang dilakukan secara harmonis sehingga mampu menciptakan situasi pembelajaran dan pendidikan yang kondusif, mampu mendorong timbulnya motivasi dan minat belajar, serta benar-benar mampu memberdayakan segenap unsur pendidikan di sekolah. ${ }^{40}$

1) Strategi Pembelajaran

Pembelajaran merupakan suatu dari berbagai komponen yang saling berhubungan satu dengan yang lainnya. Komponen tersebut meliputi tujuan, materi, metode dan evaluasi. Empat komponen pembelajaran tersebut harus diperhatikan oleh guru dalam memilih atau menentukan pendekatan dan model pembelajaran. Kegiatan pembejaran dalam implementasinya mengenal banyak istilah untuk menggambarkan cara mengajar yang akan dilakukan oleh guru. Saat ini begitu banyak macam strategi atau metode pembelajaran yang bertujuan untuk meningkatkan kualitas pembelajaran menjadi lebih baik. Istilah model pendekatan strategi metode teknik dan taktik sangat familiar dalam dunia pembelajaran kita, namun terkadang istilah-istilah tersebut membuat bingung para pendidik. ${ }^{41}$

Strategi merupakan kebijakan-kebijakan penting dari sekolah/ madrasah yang penting untuk diambil agar dapat digunakan sebagai patokan dalam pembuatan program. ${ }^{42}$ Untuk menghasilkan out put yang

\footnotetext{
${ }^{40}$ Depdiknas, Manajemen Peningkatan, 12-18

${ }^{41}$ Rusman, Manajemen Kurikulum..., 193

${ }^{42}$ Muhaimin dkk, Manajemen Pendidikan, Aplikasinya dalam Penyusunan Rencana
} 
bagus, maka perlu diperhatikan standar mutu dari proses yang dilakukan dalam lembaga. Bagi setiap institusi, mutu adalah agenda utama dan meningkatkan mutu merupakan tugas yang paling penting. ${ }^{43}$

Strategi pembelajaran adalah suatu kegiatan pembelajaran yang harus dikerjakan guru dan siswa agar tujuan pembelajaran dapat dicapai secara efektif dan efisien. Strategi pembelajaran mengandung makna perencanaan. Maksudnya pada dasarnya strategi masih bersifat konseptual, mengenai keputusan yang akan diambil dalam pelaksanaan pembelajaran. Strategi dapat diartikan sebagai suatu garis-garis besar untuk bertindak dalam usaha mencapai sasaran yang telah ditentukan. Strategi didalam dunia pendidikan dapat diartikan sebagai perencanaan yang berisi mengenai rangkaian kegiatan yang didesain untuk mencapai tujuan pendidikan tertentu. ${ }^{44}$

Cohen dalam bukunya menyinggung penilaian terhadap strategi pembelajaran, yang dirinci sebagai berikut ${ }^{45}$ :

a) every child knows how they are doing, and understands what they need to do to improve and how to get there.

b) every teacher is equipped to make well-founded judgements about pupils' attainment, understands the concepts and principles of progression, and knows how to use their assessment judgements to forward plan, particularly for pupils who are not fulfilling their potential

c) every school has in place structured and systematic assessment systems for making regular, useful, manageable and accurate assessments of pupils, and for tracking their progress

d) every parent and carer knows how their child is doing, what they need to do to improve, and how they can support the child and their teachers.

Cohen memberi gambaran bahwa antara peserta didik, guru, sekolah dan orang tua memiliki hubungan yang erat dan kontribusi terhadap strategi pembelajaran. Pertama, bahwa setiap anak tahu cara bagaimana mereka belajar, dan memahami apa yang mereka perlukan untuk meningkatkan pembelajaran dan bagaimana meju ke sana. Kedua, setiap pendidik disiapkan untuk membuat penilaian yang baik tentang pencapaian

Pengembangan Sekolah/Madrasah (Cet: 4 Jakarta: Kencana, 2012), 166

${ }^{43}$ Edward Sallis, Total Quality Management in Education; penerj, Ahmad Ali Riyadi dan Fahrurrazi (New York: Psychology press, 2002), 23

${ }^{44}$ Farudin Eko Hardiyanto, Etos Profetik Sang Pendidik, Semarang: Cipta Prima santara, 2016, 49

${ }^{45}$ Louis Cohen et all, A Guide to Teaching Practice Revised Fifth Edition, New York: Routledge, 2010, 395

FALASIFA, Vol. 9 Nomor 2 September 2018 | 13 
siswa, memahami konsep dan prinsip perkembangan, dan tahu bagaimana menggunakan penilaian mereka untuk rencana ke depan, terutama bagi murid yang tidak bisa memaksimalkan kemampuan mereka.

Ketiga, setiap sekolah memiliki sistem penilaian terstruktur dan sistematis untuk membuat penilaian terhadap peserta didik secara teratur, berguna, dapat dikelola dan akurat, dan untuk melacak kemajuan mereka. Keempat, setiap orang tua dan pengasuh tahu bagaimana keadaan anak mereka, apa yang mereka perlukan untuk menjadi lebih baik, dan bagaimana orang tua dapat mendukung anak dan guru mereka.

Strategi belajar mengajar pada sekolah efektif, harus dipusatkan pada aktifitas siswa, karena tanggung jawab ada pada siswa. Sekolah bertanggungjawab mengakomodasi kegiatan siswa agar siswa mau belajar. Hal ini berpatokan pada pengertian belajar sebagai kegiatan aktif siswa dalam membangun makna atau pemahaman. Guru perlu memberikan dorongan kepada siswa untuk menggunakan otoritasnya dalam membangun ide dan menciptakan situasi yang mendorong prakarsa, motivasi, dan tanggungjawab siswa untuk belajar sepanjang hayat. ${ }^{46}$

2) Proses Pembelajaran

Pembelajaran merupakan upaya yang dilakukan secara sadar dan sistematis. Perencanaan dan pelaksanaan pembelajaran diharapkan memiliki tujuan tertentu yang ditetapkan. Dengan demikian proses pembelajaran yang terwujud dalam interaksi peserta didik dengan guru dan juga sumber pengetahuan harus diarahkan agar pembelajar dapat memperoleh pengalaman yang bermakna. ${ }^{47}$

Sekolah sebagai tempat belajar yang memberikan layanan yang bermutu melalui strategi pembelajaran yang bervariasi, penilaian secara terus menerus, dan follow up yang cepat dan tepat, mendorong partisipasi siswa dalam pembelajaran, serta memperhatikan kehadirian siswa, pelaksanaan tugas-tugas siswa dan keberlanjutan tugas-tugasnya. ${ }^{48}$

Pembelajaran merupakan inti dari pendidikan. Selanjutnya, apabila proses pembelajarannya kondusif, mampu membuhkan inspirasi, motivasi, semangat dan kreasi-kreasi belajar, maka akan mengantarkan pada keberhasilan pendidikan. Gedung boleh sederhana, ruang kantor boleh sempit, dan posisi lembaga pendidikan Islam boleh berada di daerah

${ }^{46}$ Aan Komariah dan Cepi Triatna, Visionary Leadership Meju Sekolah Efektif, Jakarta: Sinar Grafika Offset, 2005, 48

${ }^{47}$ Tokan, Sumber Kecerdasan ..., 53

${ }^{48}$ Komariah dan Triatna, Visionary ..., 48

14 | FaLASIFA, Vol. 9 Nomor 2 September 2018 
'pinggiran', asalkan sistem pembelajarannya benar-benar kondusif masih mampu menjamin keberlangsungan proses pendidikan dengan baik. Untuk apa bangunan gedung yang megah, kantor yang mewah dan berada di tengah Kota besar jika sistem pembelajarannya siluman, pasti tidak mampu mengantarkan keberhasilan pendidikan. Sebab, pendidikan itu membutuhkan proses yang intensif dan tidak ada pendidikan yang instan. ${ }^{49}$

Proses pembelajaran merupakan kegiatan utama sekolah. Sekolah diberi kebebasan memilih strategi, metode, dan teknik pembelajaran dan pengajaran yang paling efektif, sesuai dengan karakteristik mata pelajaran, siswa, guru dan kondisi nyata sumber daya yang tersedia disekolah. Secara umum proses pembelajaran yang berpusat pada siswa lebih mampu memperdayakan siswa, dengan cara menekankan keaktifan padabelajar siswa, bukan keaktifan mengajar guru. ${ }^{50}$

3) Kegiatan Ekstra Kurikuler

Undang-Undang Nomor 20 Tahun 2003 pasal 3 tentang Sistem Pendidikan Nasional menyatakan bahwa pendidikan nasional berfungsi mengembangkan kemampuan dan membentuk watak serta peradaban bangsa yang bermartabat dalam rangka mencerdaskan kehidupan bangsa, bertujuan untuk berkembangnya potensi peserta didik agar menjadi manusia yang beriman dan bertakwa kepada Tuhan Yang Maha Esa, berakhak mulia, sehat, berilmu, cakap, kreatif, mandiri, dan menjadi warga negara yang demokratis serta bertanggung jawab. Fungsi ini kemudian diperkuat dengan tujuan pendidikan pendidikan nasional yakni untuk berkembangnya potensi peserta didik agar menjadi manusia yang beriman dan bertaqwa kepada Tuhan Yang Maha Esa, berakhlak mulia, sehat, berilmu, cakap, kreatif, mandiri, dan menjadi warga negara yang demokratis serta bertanggungjawab. ${ }^{51}$

Pernyataan di atas memiliki nilai dan makna filosofis yang dalam, artinya bahwa dalam pendidikan bukan semata-mata mengejar keterampilan intelektual tetapi juga soft skill. Pengembangan soft skill peserta didik tidak hanya dilakukan di dalam kelas yang telah terstruktur dengan jelas melalui kurikulum tetapi juga dilakukan di luar struktur. Oleh karena itu, sekolah tidak hanya memberikan stimuli dalam aktivitas kurikuler yang sudah digariskan dalam kurikulum saja, tetapi juga menyediakan di luar kurikuler

\footnotetext{
${ }^{49}$ Qomar, Strategi Pendidikan ..., 144

${ }^{50}$ Rohiyat, Manajemen Sekolah, Bandung: Refika Aditama, 2012, 65

${ }^{51}$ Undang-undang Nomor 20 Tahun 2003 tentang Sistem Pendidikan Nasional,
} pasal 3

FalAsIfA, Vol. 9 Nomor 2 September 2018 | 15 
Bustanul Arifin

dalam bentuk aktivitas ekstrakurikuler. ${ }^{52}$

Ekstrakurikuler adalah kegiatan pendidikan di luar mata pelajaran dan pelayanan konseling untuk membantu pengembangan peserta didik sesuai dengan kebutuhan, potensi, bakat, dan minat mereka melalui kegiatan yang secara khusus diselenggarakan oleh pendidik dan atau tenaga kependidikan yang berkemampuan dan berkewenangan di sekolah/ madrasah. ${ }^{53}$

Merut Permendikbud No 62 tahun 2014 Kegiatan Ekstrakurikuler adalah kegiatan kurikuler yang dilakukan oleh peserta didik di luar jam belajar kegiatan intrakurikuler dan kegiatan kokurikuler, di bawah bimbingan dan pengawasan satuan pendidikan, mulai dari tingkat dasar sampai menengah (SD s/d SMA). Kegiatan ekstrakurikuler ini diselenggarakan dengan tujuan untuk mengembangkan potensi, bakat, minat, kemampuan, kepribadian, kerjasama, dan kemandirian peserta didik secara optimal dalam rangka mendukung pencapaian tujuan pendidikan nasional. ${ }^{54}$

Kegiatan ekstrakurikuler merupakan proses yang sistematis dan sadar dalam membudayakan peserta didik agar memiliki kedewasaan sebagai bekal kehidupannya. Kegiatan ekstrakurikuler memberikan ruang yang tepat kepada peserta didik untuk mempraktikkan secara langsung (learning by doing) berbagai aktivitas yang dapat diarahkan pada upaya pembentukan karakter tertentu. ${ }^{55}$

Menrrut hasil penelitian yang dilakukan oleh Poh dan Gary, menjukkan bahwa kegiatan ektrakurikuler memiliki tiga dampak terhadap kemampuan akademik peserta didik.

First, Extracurricular Activity (ECA) participation has a negative effect on academic performance because students were devoting more time for their ECA activities at the expense of their academic studies. Second, the ECA participation has a positive effect on academic performance indirectly as a result of the non-academic and social benefits associated with ECA participation. Last, that ECA participation has a positive effect on academic performance up till a certain point beyond which 2016,1

${ }^{52}$ Dirjen Dikdasmen, Panduan Teknis Kegiatan Ekstrakurikuler di Sekolah Dasar

53 Depdiknas. 2006. Panduan Pengembangan Diri untuk Sekolah Dasar dan Menengah, Jakarta: Depdiknas, 13

${ }^{54}$ Permendikbud No 62 tahun 2014 tentang Kegiatan Ekstrakurikuler pada Pendidikan Dasar dan Pendidikan Menengah pasal 1 dan 2

${ }^{55}$ Dirjen Dikdasmen, Panduan Teknis ..., 1

16 | FALASIFA, Vol. 9 Nomor 2 September 2018 
participation leads to negative academic outcomes. ${ }^{56}$

Pertama, bahwa partisipasi dalam kegiatan ekstra kurikuler memiliki efek negatif pada kemampuan akademik peserta didik, karena mereka menghabiskan lebih banyak waktu untuk kegiatan ekstra kurikuler, dengan mengorbankan studi akademis mereka. Kedua, partisipasi dalam kegiatan ekstra kurikuler memiliki efek positif pada kemampuan akademik peserta didik secara tidak langsung, sebagai hasil dari manfaat non-akademik dan sosial yang terkait dengan kegiatan ekstra kurikuler. Terakhir, bahwa partisipasi dalam kegiatan ekstra kurikuler memiliki efek positif pada kemampuan akademik hingga melebihi titik tertentu, sehingga keterlibatan peserta didik tersebut mengarah ke hasil akademis yang negatif.

Berdasarkan paparan di atas maka sudah selayaknya jika disusun dan dikembangkan panduan teknis kegiatan ekstrakurikuler di sekolah dasar, sehingga memberikan kemudahan bagi pemangku kepentingan pendidikan dalam melaksanakan kegiatan ekstrakurikuler khususnya di sekolah dasar. Upaya ini perlu dilakukan secara terus menerus karena kegiatan ekstrakurikuler bukan menjadi pelengkap semata dalam proses pendidikan secara menyeluruh di sekolah. Sekolah perlu menyusun rencana, pelaksanaan, evaluasi, pengembangan, dan tindak lanjut agar ekstrakurikuler tidak hanya sekedar pengisi waktu luang siswa akan tetapi merupakan sarana yang penting dalam mengembangan potensi peserta didik. ${ }^{57}$

c. Peningkatan Mutu Out put

Out put sekolah dalam bidang akademik misalnya meningkatnya nilai ujian nasional, bertambahnya jumlah lulusan yang diterima di Perguruan Tinggi Negeri (PTN) dan Perguruan Tinggi Swasta (PTS) unggulan, menjadi pemenang dalam berbagai olimpiade akademik. Sedangkan out put sekolah dalam bidang non akademik misalnya kejujuran, kedisplinan, kerja sama yang baik, solidaritas yang tinggi, dan toleransi serta meningkatnya prestasi olahraga, seni, dan kegiatan sosial yang berhubungan langsung dengan kegiatan pembinaan masyarakat. ${ }^{58}$

Mutu out put dalam hal ini didasarkan pada Standar Kompetensi Lulusan ${ }^{59}$ yang tercantum dalam PP No 19 tahun 2005. Standar kompetensi

${ }^{56}$ Poh Sun SEOW, and Gary Shan Shi PAN. A Literature Review of the Impact of Extracurricular Activities Participation on Students' Academic Performance. (2014). Journal of Education for Business. 89, (7), 361-366. Research Collection School Of Accountancy, 11

${ }^{57}$ Dirjen Dikdasmen, Panduan Teknis ... 2016

${ }^{58}$ Depdiknas, Manajemen Peningkatan, 12-18

${ }^{59}$ Peraturan Pemerintah Republik Indonesia No 19 tahun 2005 tentang Standar

FALASIFA, Vol. 9 Nomor 2 September 2018 | 17 


\section{Bustanul Arifin}

lulusan digunakan sebagai pedoman penilaian dalam penentuan kelulusan peserta didik dari satuan pendidikan. Kompetensi lulusan untuk mata pelajaran bahasa menekankan pada kemampuan membaca dan melis yang sesuai dengan jenjang pendidikan. Kompetensi lulusan mencakup sikap, pengetahuan, dan keterampilan.

Standar kompetensi lulusan pada jenjang pendidikan dasar bertujuan untuk meletakkan dasar kecerdasan, pengetahuan, kepribadian, ahklak mulia, serta, keterampilan untuk hidup mandiri dan mengikuti pendidikan lebih lanjut. Standar kompetensi lulusan pendidikan dasar dan menengah dan pendidikan nonformal dikembangkan oleh BSNP dan ditetapkan dengan Peraturan Menteri. ${ }^{60}$

\section{KESIMPULAN}

Agar mutu out put menjadi terjamin, maka dalam pelaksanaan dan prosesnya diatur oleh Standar Pelayanan Minimal (SPM) Pendidikan Sekolah Dasar (SD)/Madrasah Ibtida'iyah (MI). SPM untuk SD/MI ini diatur oleh Keputusan Mendiknas. SPM SD/MI merut Kepmendiknas ini antara lain : 95 persen anak dalam kelompok usia 7-12 tahun bersekolah di SD/MI. Angka Putus Sekolah (APS) tidak melebihi 1 persen dari jumlah siswa yang bersekolah. 90 persen sekolah memiliki sarana dan prasarana minimal sesuai dengan standar teknis yang ditetapkan secara nasional. 90 persen dari jumlah guru SD yang diperlukan terpehi. 90 persen guru SD/MI memiliki kualifikasi sesuai dengan kompetensi yang ditetapkan secara nasional. 95 persen siswa memiliki buku pelajaran yang lengkap setiap mata pelajaran. Jumlah siswa SD/MI per kelas antara 30 - 40 siswa. 90 persen dari siswa yang mengikuti uji sampel mutu pendidikan standar nasional mencapai nilai "memuaskan" dalam mata pelajaran membaca, melis dan berhitung untuk kelas III dan mata pelajaran bahasa, matematika, IPA dan IPS untuk kelas V. 95 persen dari lulusan SD melanjutkan ke Sekolah Menengah Pertama (SMP)/Madrasah Tsanawiyah (MTs).

\section{DAFTAR PUSTAKA}

A. Malik Fajar, Reorientasi Pendidikan Islam, (Jakarta: Fajar Dunia, 1999) Aan Komariah dan Cepi Triatna, Visionary Leadership Meju Sekolah Efektif, Jakarta: Sinar Grafika Offset, 2005

Abdul Latif, Pengembangan Sumber Daya Manusia yang Berkualitas Menghadapi

Nasional Pendidikan pasal 25-27

${ }^{60} \mathrm{ibid}$

18 | FalASIFA, Vol. 9 Nomor 2 September 2018 
Meningkatkan Mutu Pendidikan Melalui Manajemen Peserta Didik

Era Pasar Bebas, (Jakarta: DPP HIPPI, 1996)

Ahmad Sasi, Pendidikan Alternatif, (Bandung: Grafindo Media Pratama, 1998)

Ali Imron, Manajemen Peserta Didik di SD: Masalah, Penyebab, dan Alternatif

Pemecahannya, Jurnal Ilmu Pendidikan, e-ISSN 2442-8655 Volume 5

Nomor 1 tahun 1998

Dave Meier, The Accelerated Learning Handbook, New York: The McGraw-Hill Companies, Inc, 2000

Depdiknas, Manajemen Peningkatan Mutu Berbasis Sekolah, Buku 1, Konsep dan Pelaksanaan (Jakarta: Dirjen Dikdasmen, 2001)

Depdiknas. 2006. Panduan Pengembangan Diri untuk Sekolah Dasar dan Menengah, Jakarta: Depdiknas

Destyana Ratih Pramachintya, dan Budi Sutrisno, Strategi Penerimaan Peserta

Didik Baru di SD Muhammadiyah Program Khusus Boyolali, Jurnal VARIDIKA, p-ISSN 0852-0976 Volume 27 Nomor 1 tahun 2015

Dirjen Dikdasmen, Panduan Teknis Kegiatan Ekstrakurikuler di Sekolah Dasar 2016

Edward Sallis, Total Quality Management in Education, Yogyakarta: Ircisod, 2015

Edward Sallis, Total Quality Management in Education; penerj, Ahmad Ali Riyadi dan Fahrurrazi (New York: Psychology press, 2002)

Eka Prihatin, Manajemen Peserta Didik, (Bandung: Alfabeta, 2014),

Farudin Eko Hardiyanto, Etos Profetik Sang Pendidik, Semarang: Cipta Prima santara, 2016

Hamiyah dan Mohammad Jauhar, Pengantar Manajemen Pendidikan di Sekolah, (Jakarta: Prestasi Pustaka, 2015)

Imam Machali, dan Ara Hidayat, The Handbook Education Management, Jakarta: Prenadamedia Group, 2016

Imron, Manajemen Peserta Didik Berbasis Sekolah, (Jakarta: Bumi Aksara, 2015),

J. S. Lawes, and CT Eddy, Understanding Children, An Introduction To Psychology For African Teachers, London: Taylor \& Francis, 1966

Joseph M. Juran and A. Blanton Godfrey, Juran's Quality Handbook Fifth Edition, New York: The McGraw-Hill Companies, Inc, 1998

Karwati, Euis, dan Priansa, Donni Juni, Manajemen Kelas, (Bandung: Alfabeta, 2015)

Keputusan Menteri Pendidikan Nasional Nomor 129a/U Tahun 2004 tentang Standar Pelayanan Minimal Bidang Pendidikan

Louis Cohen et all, A Guide to Teaching Practice Revised Fifth Edition, New York: Routledge, 2010

Maulida dkk, Manajemen Sarana dan Prasarana Pendidikan pada SMA Negeri 5

FALASIFA, Vol. 9 Nomor 2 September $2018 \mid 19$ 
Bustanul Arifin

Banda Aceh, Jurnal Mudarrisuna, e-ISSN 2460-0733 Volume 6 Nomor 1

Muhaimin dkk, Manajemen Pendidikan, Aplikasinya dalam Penyusunan Rencana

Pengembangan Sekolah/Madrasah (Cet: 4 Jakarta: Kencana, 2012)

Mujamil Qomar, Manajemen Pendidikan Islam, (Jakarta: Erlangga, 2007) , Strategi Pendidikan Islam, (Jakarta: Penerbit Erlangga, 2013)

Mulyasa, Manajemen Berbasis Sekolah cet 15, (Bandung: PT Remaja Rosdakarya, 2012)

P. Ratu Ile Tokan, Sumber Kecerdasan Manusia, Jakarta: Grasindo, 2016

Peraturan Pemerintah Nomor 32 tahun 2013 tentang perubahan atas Peraturan

Pemerintah No 19 tahun 2005 tentang Standar Nasional Pendidikan

Peraturan Pemerintah Republik Indonesia No 19 tahun 2005 tentang Standar

Nasional Pendidikan

Permendikbud No 62 tahun 2014 tentang Kegiatan Ekstrakurikuler pada

Pendidikan Dasar dan Pendidikan Menengah pasal 1 dan 2

Permendiknas Nomor 20 tahun 2007, tentang Standar Penilaian Pendidikan

Poh Sun SEOW, and Gary Shan Shi PAN. A Literature Review of the Impact of

Extracurricular Activities Participation on Students' Academic Performance.

(2014). Journal of Education for Business. 89, (7), 361-366. Research

Collection School Of Accountancy

Ramayulis, Ilmu Pendidikan Islam, (Jakarta: Kalam Mulia, 2008)

Regina M. Oliver and Daniel J. Reschly, Effectife Classroom Management: Teacher

Preparation and Professional Development, Washington: National

Comprehensive Centre for Teacher Quality, 2007

Rohiyat, Manajemen Sekolah, Bandung: Refika Aditama, 2012,

Sitiatava Rizema Putra, Desain Evaluasi Belajar Berbasis Kinerja, Yogayakarta: Diva

Press, 2013

Tim Dosen Administrasi Pendidikan UPI, Manajemen Pendidikan, (Bandung: Alfabeta, 2011)

Tokan, P. Ratu Ile, Sumber Kecerdasan Manusia, Jakarta: Grasindo, 2016

Undang-undang No 20 tahun 2003 tentang Sistem Pendidikan Nasional

Veithzal Rivai Zainal dkk, Islamic Quality Education Management, Jakarta:

Gramedia, 2016

20 | FaLASIFA, Vol. 9 Nomor 2 September 2018 